\title{
CHANGES IN POPULATION STRUCTURES OF THE MAJOR FISH SPECIES IN SELECTED SATELLITE LAKES AROUND LAKE VICTORIA FOLLOWING CHANGES IN FISHING EFFORT
}

\author{
${ }^{1}$ EFB Katunzi and ${ }^{2}$ MA Kishe \\ Tanzania Fisheries Research Institute, \\ PO Box 475, Mwanza, Tanzania \\ ${ }^{1}$ katunzi2002@hotmail.com, ${ }^{2}$ maria_kishe@yahoo.co.uk
}

Accepted 10 September 2004

\begin{abstract}
This paper evaluates the impacts of reduction in effort, increase in mesh sizes, and prohibition of illegal fishing gears in selected satellite lakes around Lake Victoria. The study was carried out in six satellite lakes by making investigations on fish collected from experimental and artisanal fisheries. The fishes were analysed for length frequencies, weight and numbers caught to determine the population structure of the fishes. Indiscriminate fishing by deploying illegal gears and increased fishing effort due to open access policy, the catch and diversity of the species in these lakes has declined. Establishment of Conservation Management Units (CMUs) as an enforcement measure in some satellite lakes seems to succeed in controlling the illegal practices and a positive sign of recovery of some species and size increase of the exploitable fish species was noted in lakes Ikimba and Kirumi where enforcement has been effected. From March 2002 to January 2003 the maximum size of Oreochromis niloticus and O. esculentus had increased from $28 \mathrm{~cm}$ to $33 \mathrm{~cm}$ and $25 \mathrm{~cm}$ to $27 \mathrm{~cm}$ in Lake Kirumi and Lake Ikimba, respectively. Nevertheless, fish species diversity in these lakes is still low. Recommendations on the way forward are given
\end{abstract}

\section{INTRODUCTION}

Satellite lakes have not only served as natural species reservoirs (Katunzi 2003) but also have influenced the socio-economic outlook of the indigenous populations of human being in the Lake Victoria basin (Harris 1998). Apart from Lates niloticus and Rastrineobola argentea, data collected for the last five years has confirmed the presence of fish species in satellite lakes to be similar to those indigenous to Lake Victoria (Katunzi and Msuku 2001). Recent attempts to study biodiversity in satellite lakes (Lyimo and Sekadende 2003, Katunzi 2003) have also paved way for the resolution of the intricacies within these isolated water bodies. The available data so far indicate that the fisheries within satellite lakes are declining (Katunzi and Msuku 2001, Katunzi and Kishe 2002, Katunzi 2003) while little is known on the ecosystems and population structures. Heavy fishing pressure, free access to the fisheries, continual use of illegal fishing gear have greatly affected the commonly exploited species.

To keep the biological entity while preseving the aesthetics, there is need to address the fisheries management issues so as to minimize possible changes that could lead to species extinction. Untill recently, there has not been any initiative to involve the fishers and communities in supporting and applying biological findings. This has resulted in over-exploitation of fisheries resources manifested as reduced age and size at first maturity of fish species, as well as high fishing mortalities and decline in catch rates and fish diversities in these minor water bodies (Katunzi 2003). As a measure to combact further declines, Conservation Management Units (CMUs) were established to participate in the management process. Over the last two years, a positive sign of species recovery and size increment of some 
fish species in the satellite lakes has been noted (Katunzi and Msuku 2001, Katunzi and Kishe 2002, Katunzi 2003). The common species in satellite lakes are Oreochromis species (i.e. O. niloticus, $O$. esculentus and $O$. leucostictus), Clarias gariepinus and Protopterus aethiopicus (opp. cited). This paper speculates on the reasons behind these recoveries, changes in fish population structures following changes in fishing effort and suggests appropriate measures that will help to sustain the fish species in the satellite lakes.

\section{MATERIALS AND METHODS}

The study was carried out in March 2002, September 2002 and January 2003 in lakes
Burigi, Malimbe, Ikimba, Kirumi, Kubigena, and Katwe (Fig. 1). Fishery data was collected from the satellite lakes using data from the fishermen (dependent) and experimental fishing (independent). Independent fishing was carried out using multi-mesh gillnets whose panels had mesh sizes ranging from $2.5 \mathrm{~cm}$ to $12.5 \mathrm{~cm}$ at $1.25 \mathrm{~cm}$ interval. The nets were set in the evening, left overnight and hauled early the next morning. Collected fish samples were identified to species level, grouped into size classes per gillnet mesh size basing on total length $(\mathrm{cm})$ measurements. Data was analysed for length frequency distribution and percentage species compositions.

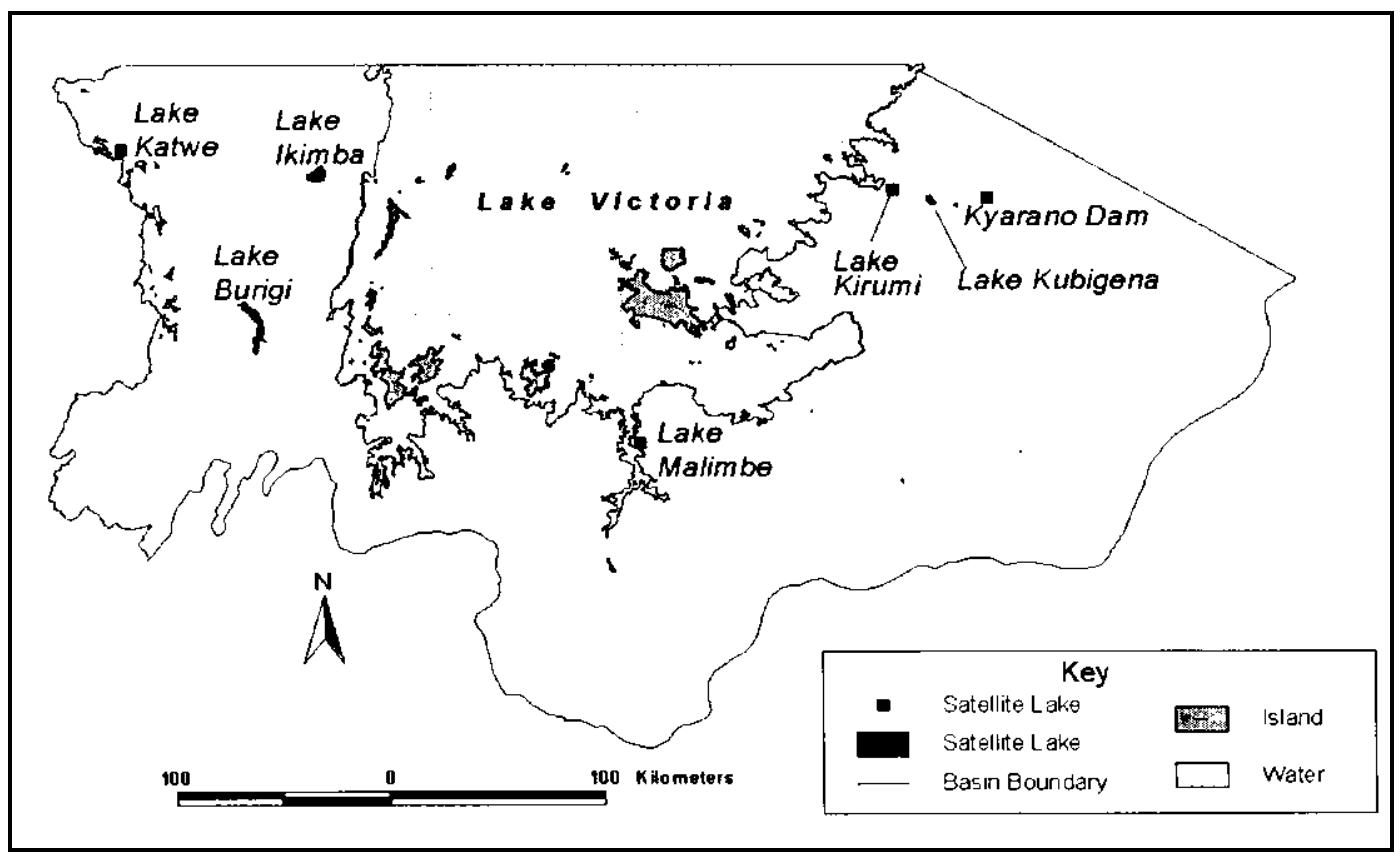

Figure 1: Map of Lake Victoria showing sampling stations

Data from dependent fishery was analysed by taking length frequencies and weights of the landed fishes per boat at lakes Burigi and Kubigena. Fishermen were using gillnets of mesh sizes $5.0 \mathrm{~cm}, 7.5 \mathrm{~cm}$ and $8.5 \mathrm{~cm}$ in both lakes while in Lake
Kubigena hooks of size 9 and 10 were also in use. The length modes from the catch data were reported and discussed with relation to lengths at $50 \%$ maturity as per Katunzi and Msuku (2001) to establish the level of exploitation for $O$. esculentus from lakes Burigi, Malimbe and Ikimba. 


\section{RESULTS}

The majority of the fish species reported missing, for example, Oreochromis esculentus, O. leucostictus, Momyrus species in Lake Victoria were found in these satellite lakes.

\section{Lake Burigi}

Lake Burigi was characterised by an artisanal fishery based on Oreochromis esculentus, $O$. niloticus, $O$. variabilis, Clarias gariepinus and Protopterus aethiopicus. The three Oreochromis species coexist but $O$. esculentus was captured from further offshore waters. Catches from both independent fishery (Table 1) and dependent fishery (pers. observ.) were dominated by $O$. esculentus in terms of weights and numbers. Other fish species that were found but at low percentages include Clarias gariepinus, Tilapia zillii, Barbus profundus, Astatoreochromis alluadi and three phytoplanktivorous haplochromines (Table 1).

Table 1. Percentages composition by number and weight $(\mathrm{kg})$ of fish species in Lake Burigi

\begin{tabular}{lcccccc}
\hline \multirow{2}{*}{ Fish species } & \multicolumn{2}{c}{ March 2002 } & \multicolumn{2}{c}{ September 2002 } & \multicolumn{2}{c}{ January 2003 } \\
\cline { 2 - 7 } & Weight & Number & Weight & Number & Weight & Number \\
\hline O. variabilis & 7.1 & 14.0 & 5.1 & 0.3 & 24.9 & 14.5 \\
O. esculentus & 22.1 & 33.1 & 78.4 & 90.5 & 20.2 & 38.2 \\
O. niloticus & 10.7 & 9.9 & 2.4 & 5.1 & 30.7 & 11.6 \\
T. zillii & 0.2 & 0.4 & - & - & 1.1 & 0.3 \\
B. profundus & 0.1 & 4.6 & - & - & 0.0 & 0.8 \\
C. gariepinus & 59.8 & 9.1 & 13.7 & 1.7 & 23.1 & 1.8 \\
P. aethiopicus & - & - & - & - & 0.01 & 0.1 \\
Haplochromines & 0.04 & 29.1 & 0.3 & 2.4 & 0.01 & 32.7 \\
\hline
\end{tabular}

From the independent fishery data in March 2002, the maximum lengths of Oreochromis esculentus caught was $22 \mathrm{~cm}$ TL (Fig. 2a) whereas in September 2002, the biggest size was $35 \mathrm{~cm}$ TL (Fig. 2b). However, the January 2003 survey indicated a size decrease to $29 \mathrm{~cm} \mathrm{TL}$ (Fig. 2c). In the latter two surveys, larger fishes were caught compared to the March 2002 catch.

The dependent fishery data indicate that the mode of the exploited population was $17 \mathrm{~cm}$ TL (Figs $3 a \& b)$.

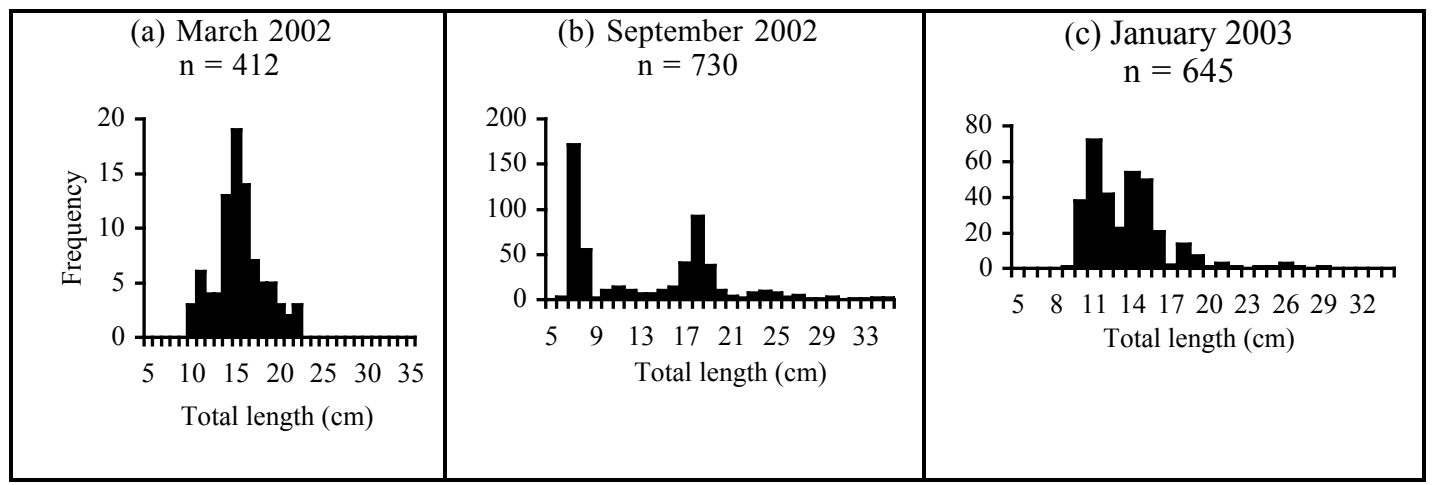

Figure2: Length frequency distribution of $O$. esculentus catches in Lake Burigi (experimental/independent fishery) 


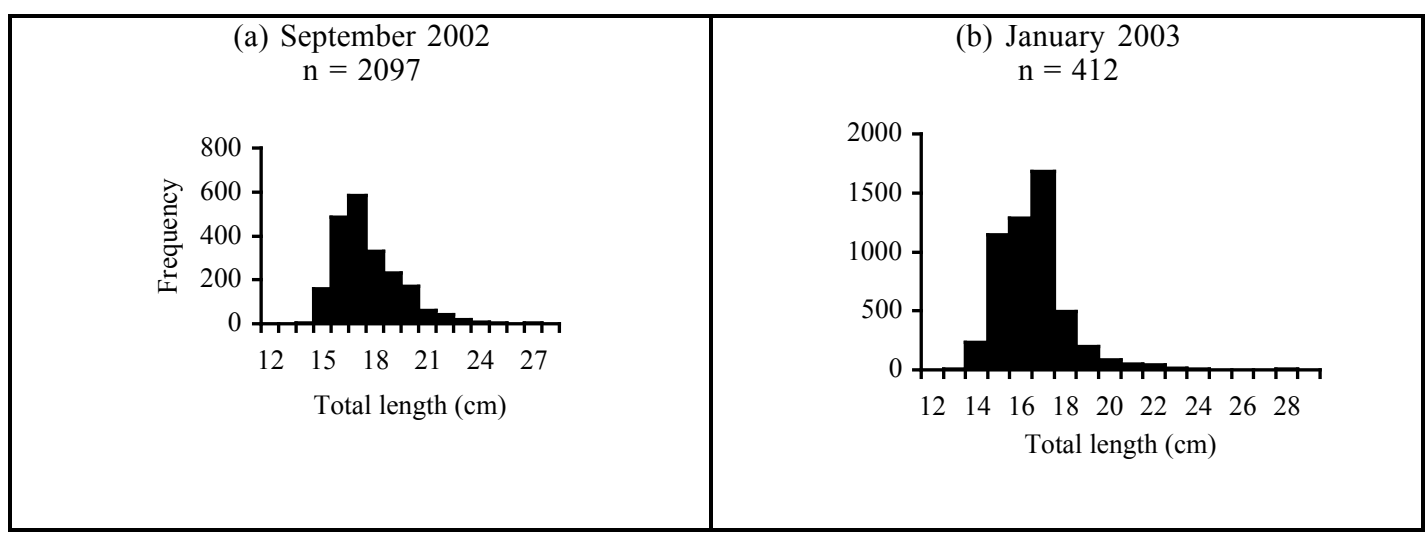

Figure 3: $\quad$ Length frequency distribution for O. esculentus in Lake Burigi showing a range of exploited population (dependent fishery)

Table 2. Percentages composition by number and weight $(\mathrm{kg})$ of fish species caught by gillnets in Lake Ikimba

\begin{tabular}{lcccccc}
\hline & \multicolumn{2}{c}{ March 2002 } & \multicolumn{2}{c}{ September 2002 } & \multicolumn{2}{c}{ January 2003 } \\
\hline Fish species & Weight & Number & Weight & Number & Weight & Number \\
\hline B. sadleri & 3.6 & 12.6 & - & - & 2.8 & 13.3 \\
O. esculentus & 35.9 & 77.2 & 13.8 & 45.8 & 11.3 & 8.3 \\
B. profundus & 0.4 & 4.6 & - & - & 0.2 & 0.7 \\
C. gariepinus & 50.0 & 2.8 & 61.9 & 22.1 & 39.6 & 1.7 \\
P. aethiopicus & - & - & - & - & 36.9 & 8.0 \\
Haplochromines & 10.0 & 2.8 & 22.9 & 31.7 & 5.8 & 48.7 \\
O. variabilis & - & - & 1.4 & 0.4 & - & - \\
M. rheni & - & - & - & - & 3.4 & 19.3 \\
\hline
\end{tabular}

\section{Lake Ikimba}

Oreochromis esculentus continued to dominate the gillnet fishery of Lake Ikimba for three different sampling periods (Table 2). Among the haplochromines caught were Prognathochromis venator, Astatotilapia velifer, A. lacrimosa and Astatoreochromis alluadi. There was an increase in the number of fish species from 5 (March 2002 survey) to 7 species (January 2003 survey). Fish species that were not caught in previous surveys are Protopterus aethiopicus and M. rheni.

The modal length of fish in Septmber 2002 (Fig. 4a) and January 2003 (Fig. 4b) was the same ranging from $8-11 \mathrm{~cm}$ TL. However, the 2003 data indicated a high number of bigger size categories of fish (Fig. 4b).

\section{Lake Katwe}

Though Lake Katwe had the highest number of fish species (Table 3), the number decreased from 15 (March 2002) to 13 (September 2002) and then to 11 (January 2003) (Table 3). The haplochromine group was dominated by an unidentified algal scraper and Astatoreochromis alluadi. Other species identified include Xystichromis sp, Gaurochromis simpsoni and Psamochromis sp. All the four tilapiine species were exploited from this lake with $O$. niloticus and $O$. leucostictus dominating compared to $O$. esculentus and $O$. variabilis. Brycinus jacksonii, O. variabilis, G. longibarbis, S. intermedius, $P$. catastoma, T. zillii and $P$. aethiopicus that were collected during March 
2002 were not recorded in the catch of January 2003 survey. The lake has been exploited heavily without any management measures. The catch rates had declined from 22.2 (in 2002) to $16.4 \mathrm{~kg} /$ boat (in 2003 .

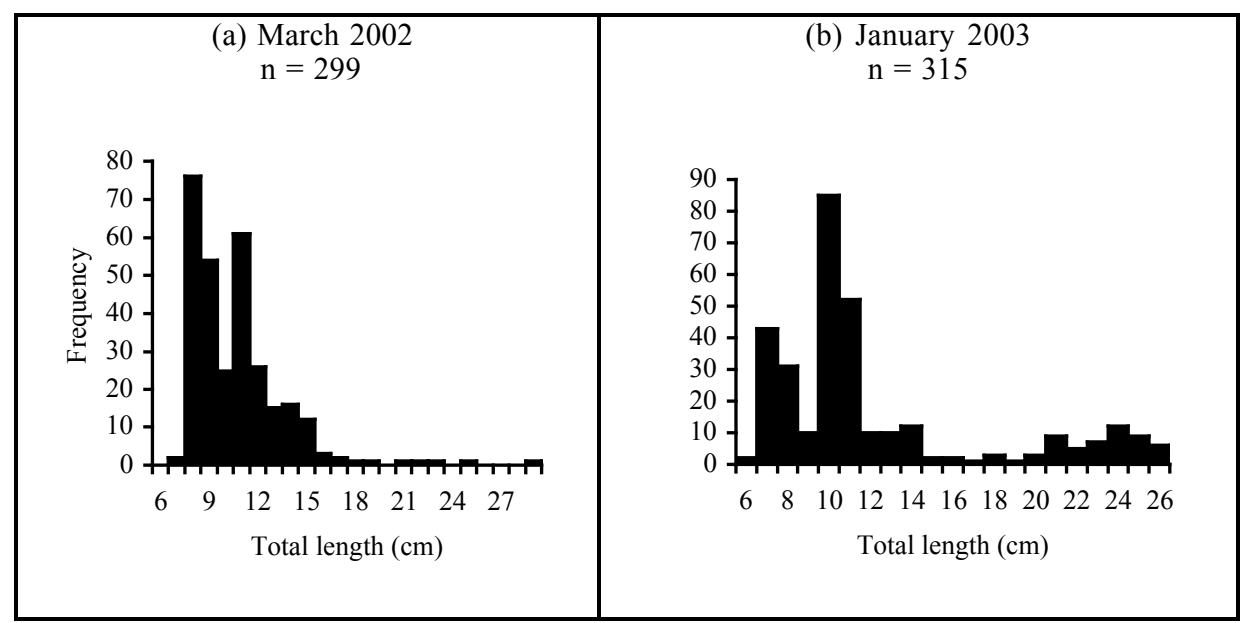

Figure 4. Length frequency distribution of exploited $O$. esculentus caught by gillnetLake Ikimba

Table 3. Percentages composition by number and weight $(\mathrm{kg})$ of fish species in Lake Katwe

\begin{tabular}{lcccccc}
\hline \multirow{2}{*}{ Fish species } & \multicolumn{2}{c}{ March 2002 } & \multicolumn{2}{c}{ September 2002 } & \multicolumn{2}{c}{ January 2003 } \\
\cline { 2 - 7 } Beight & Number & Weight & Number & Weight & Number \\
B. jacksonii & 0.1 & 0.4 & 0.2 & 0.3 & 2.3 & 1.5 \\
O. leucostictus & 4.6 & 5.5 & 9.1 & 0.3 & - & - \\
O. variabilis & 6.0 & 5.9 & 4.1 & 11.6 & 28.9 & 11.6 \\
S. intermedius & 1.3 & 0.8 & 0.9 & 0.8 & 1.1 & - \\
L. victorianus & 0.5 & 0.4 & 2.1 & 1.9 & 4.1 & 1.1 \\
O. esculentus & 13.8 & 37.1 & - & - & 2.5 & 1.1 \\
O. niloticus & 27.1 & 33.7 & 9.2 & 8.6 & 4.1 & 0.5 \\
S. victoriae & 0.2 & 0.5 & - & - & 0.6 & 0.8 \\
B. altianalis & & & 0.3 & 1.9 & 1.6 & 3.2 \\
C. gariepinus & 39.8 & 7.6 & 6.5 & 1.1 & 17.1 & 0.9 \\
Haplochromines & 0.9 & 2.5 & 54.2 & 30.7 & 37.7 & 78.8 \\
S. afrofischeri & 1.0 & 1.3 & 12.5 & 38.5 & - & - \\
G. longibarbis & 0.1 & 0.8 & - & - & - & - \\
$P$. catastoma & 0.1 & 0.4 & 0.2 & 0.6 & - & - \\
T. zillii & 3.9 & 2.1 & - & - & - & - \\
C. alluadii & - & - & - & - & 0.1 & 0.2 \\
$P$. aethiopicus & 0.6 & 0.4 & - & - & - & - \\
M. rheni & 0.1 & 0.4 & 1.4 & 0.6 & & \\
\hline
\end{tabular}




\section{Lake Kirumi}

The species composition at Lake Kirumi observed in January 2003 had changed compared to earlier studies results (Table 4). Phytoplanktivorous haplochromines, $O$. niloticus, $P$. aethiopicus and $B$. altianalis made up the highest percentages both in terms of numbers and weights (Table 4). Barbus altianalis was now dominating the Lake Kirumi catches. Also, haplochromines and $O$. niloticus were contributing high percentages both by numbers and weights (Table 4). Though the maximum size of $O$. niloticus caught in September 2002 and January 2003 remained at $33 \mathrm{~cm} \mathrm{TL}$, the modal length had shifted from $19 \mathrm{~cm}$ TL (Fig. 5a) to $27-30 \mathrm{~cm}$ TL (Fig. 5b) respectively. However, the catch per net was still low.

Table 4. Percentages composition by number and weight $(\mathrm{kg})$ of fish species in Lake Kirumi

\begin{tabular}{|c|c|c|c|c|c|c|}
\hline \multirow[b]{2}{*}{ Fish species } & \multicolumn{2}{|c|}{ March 2002} & \multicolumn{2}{|c|}{ September 2002} & \multicolumn{2}{|c|}{ January 2003} \\
\hline & Weight & Number & Weight & Number & Weight & Number \\
\hline B. sadleri & & & & & 2.9 & 13.0 \\
\hline O. esculentus & & & & & 5.2 & 6.3 \\
\hline O. niloticus & 21.2 & 14.3 & 34.6 & 3.0 & 53.5 & 8.7 \\
\hline O. leucostictus & & & 6.9 & 1.2 & & \\
\hline B. altianalis & & & 5.4 & 6.3 & 12.7 & 42.3 \\
\hline C. gariepinus & 43.9 & 4.8 & 23.5 & 0.3 & 1.1 & 0.3 \\
\hline P. aethiopicus & 26.0 & 23.8 & 3.4 & 0.2 & 18.5 & 1.7 \\
\hline Haplochromines & & & 49.7 & 89.4 & 5.6 & 26.3 \\
\hline S. afrofischeri & 8.9 & 57.1 & 4.8 & 4.0 & & \\
\hline C. alluadi & & & & & 0.5 & 1.3 \\
\hline
\end{tabular}

\begin{tabular}{|c|c|c|}
\hline 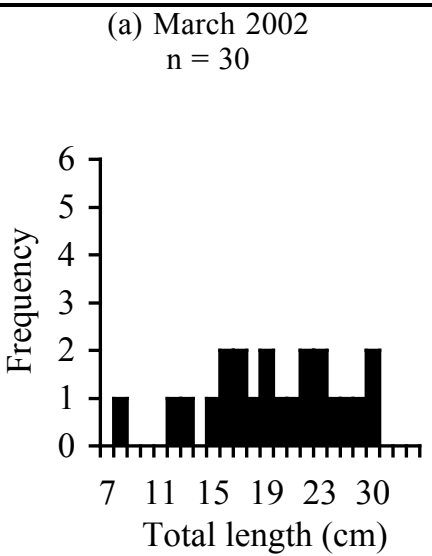 & $\begin{array}{l}\text { (a) September } 2002 \\
\mathrm{n}=44 \\
6 \\
0 \\
0 \\
0 \\
5 \\
5 \\
\text { Total length }(\mathrm{cm})\end{array}$ & 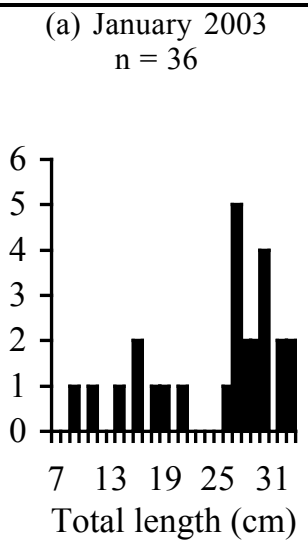 \\
\hline
\end{tabular}

Figure 5. Length frequency distribution of $O$. niloticus catches in Lake Kirumi

\section{Lake Malimbe}

Lake Malimbe has an important small-scale fishery based on Oreochromis esculentus. The 2002 and 2003 surveys revealed a decline in modes at $11 \mathrm{~cm}$ (Fig. 6a) and 7 $\mathrm{cm}$ TL (Fig. 6b) respectively. Other fish species e.g. P. aethiopicus, C. gariepinus 
and haplochromines were also found but in very small quantities (Table 5).

Table 5. Percentages composition by number and weight $(\mathrm{kg})$ of fish species in Lake Malimbe

\begin{tabular}{lcccccc}
\hline & \multicolumn{2}{c}{ March 2002 } & \multicolumn{2}{c}{ September 2002 } & \multicolumn{2}{c}{ January 2003 } \\
\hline Fish species & Weight & Number & Weight & Number & Weight & Number \\
\hline O. esculentus & 40.8 & 1.0 & 44.0 & 74.0 & 90.2 & 79.2 \\
C. gariepinus & 22.6 & 1.0 & 32.0 & 21.2 & - & - \\
P. aethiopicus & 29.1 & 78.7 & - & - & 4.1 & 19.3 \\
Haplochromines & 6.0 & 8.2 & 5.8 & 5.4 & 5.8 & 20.6 \\
T. rendalli & 1.6 & 1.0 & - & - & - & - \\
\hline
\end{tabular}

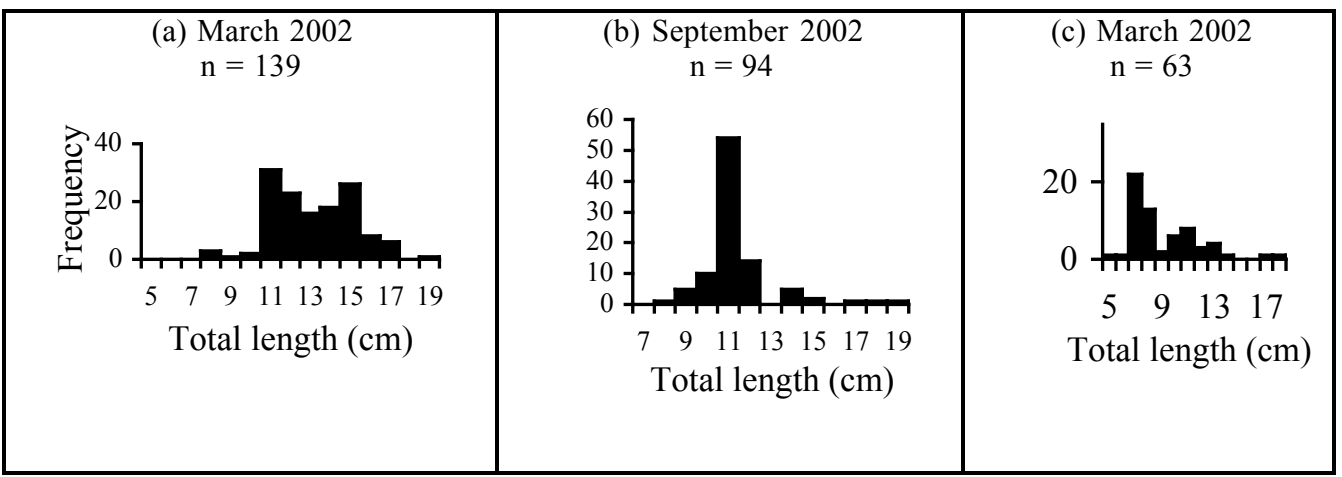

Figure 6. Length frequency distribution of $O$. esculentus caught by gillnet in Lake Malimbe

\section{Lake Kubigena}

The lake supports a fishery based on Oreochromis leucostictus, O. niloticus, Clarias gariepinus and Protopterus aethiopicus (Table 6). Due to open access the fishery and continued use of illegal fishing gears and methods (e.g. spears), the species are exploited before reaching maturity as recorded by Mossile and Mainoya (1988). Protopterus aethiopicus and $C$. gariepinus dominated the catch in terms of numbers and weights for the three surveys (March 2002, September 2002 and
January 2003) (Table 6). The collected $C$. gariepinus had size ranges of 24-67 cm TL (September 2002) (Fig. 7a) and 22-70 cm TL (January 2003) (Fig. 7b) with modal length of $37 \mathrm{~cm} \mathrm{TL}$ and $32 \mathrm{~cm} \mathrm{TL}$ respectively. Protopterus aethiopicus caught in Lake Kubigena in September 2002 and January 2003 had respective sizes of 34 $125 \mathrm{~cm}$ TL (Fig. 8a) and $37-114 \mathrm{~cm} \mathrm{TL}$ (Fig. 8b). Respective modal length are 48 $\mathrm{cm} \mathrm{TL}$ and $51-53 \mathrm{~cm} \mathrm{TL}$ 
Table 6. Percentages composition by number and weight $(\mathrm{kg})$ of fish species caught by gillnet in Lake Kubigena

\begin{tabular}{lcccccc}
\hline & \multicolumn{2}{c}{ March 2002 } & \multicolumn{2}{c}{ September 2002 } & \multicolumn{2}{c}{ January 2003 } \\
\hline Fish species & Weight & Number & Weight & Number & Weight & Number \\
\hline O. leucostictus & 41.5 & 1.3 & 9.0 & 11.6 & 8.3 & 11.6 \\
O. variabilis & 1.5 & 0.1 & - & - & - & - \\
L. victorianus & 0.3 & 0.0 & - & - & - & - \\
O. niloticus & 3.8 & 0.3 & - & - & - & - \\
C. gariepinus & 18.2 & 77.4 & 16.7 & 16.1 & 36.7 & 53.3 \\
P. aethiopicus & 34.6 & 20.9 & 74.3 & 71.4 & 55.0 & 35.1 \\
\hline
\end{tabular}

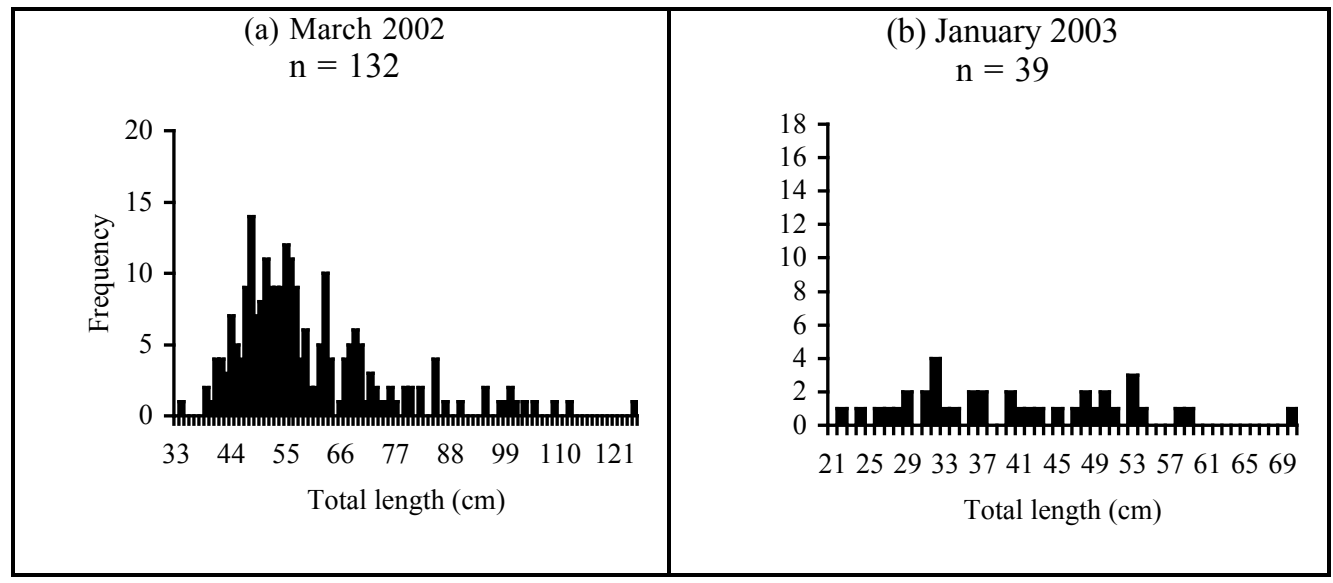

Figure 7. Length frequency distribution of exploited C. gariepinus in Lake Kubigena caught by gillnet and hooks (dependent fishery)

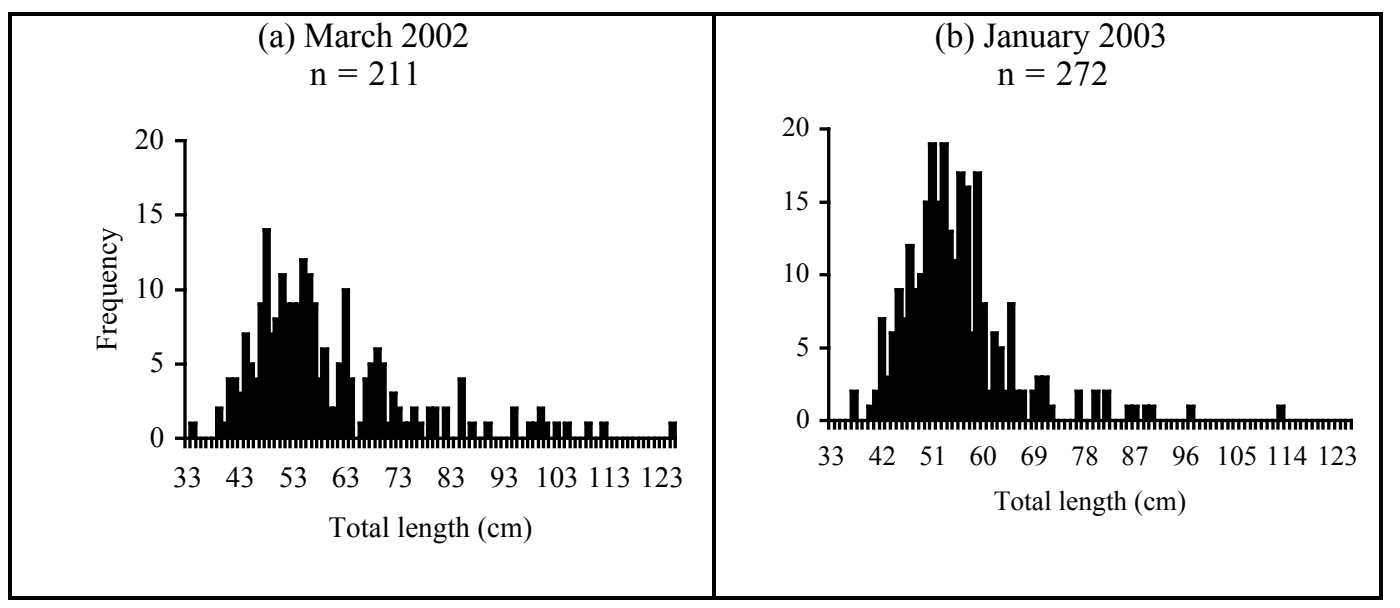

Figure 8. Length frequency distribution of P. aethiopicus in Lake Kubigena showing the range of exploitation population caught by gillnets and hooks (dependentfishery) 


\section{DISCUSSION}

The increase in diversity in the month of September was probably a result of increase in food items (phytoplankton and zooplankton species) in the environment as a result of the rains. The level of species diversity in each lake does not however guarantee unrestricted harvesting. At Lakes Ikimba and Kirumi, where the communities positively responded to the initiative of establishing Conservation Management Units (CMUs) (pers. obs), an increase in sizes of fish and number of species has been registered. At Lake Ikimba, the increase is also due to an effective enforcement of increased mesh size and prohibiting of bad fishing practices. On the other hand, a slight recovery of some fish species e.g Barbus altianalis, $O$. niloticus at Lake Kirumi was because no fishing was taking place. Also, haplochromines were observed though in small numbers.

The apparent size increase of $O$. esculentus at Lake Burigi (during September 2002 survey) was probably a result of reduced fishing effort since fishing was stopped for three months due to lack of security within the area. The slight drop of size observed during January 2003 survey suggests that the resources are sensitive to fishing pressure. Currently, the size of $O$. esculentus exploited coincides with $\mathrm{L}_{\mathrm{m} 50}$ of $16.6 \mathrm{~cm}$ TL for females and $16.5 \mathrm{~cm} \mathrm{TL}$ for males (Katunzi and Msuku 2001). This suggests that by further reducing the fishing effort, fishes at Lake Burigi could grow to bigger sizes. Increase in mesh size to $7.5-10 \mathrm{~cm}$ is recommended, so as to give chance to many fishes to reproduce before they are caught.

Lake Malimbe stands out as an example of a unmanaged fishery. Due to socio-economic reasons and lack of proper sensitization of the CMUs, the fishers have continued to exploit fish using under sized gillnets. This, combined with the splashing water method locally known as "katuli", has caused a decrease in the modal class of the exploited population (O. esculentus) from $11 \mathrm{~cm}$ TL (March and September 2002) to $7 \mathrm{~cm} \mathrm{TL}$
(January 2003). Despite the low modal lengths, the exploited fishes were mature. Also the lengths at $50 \%$ maturity were low compared to those in the main lake (Witte and Van Densen 1995).

The fishery at Lake Kubigena exploits both Protopterus aethiopicus and Clarias gariepinus. However, the exploitation rate was very high and the catch was dominated by immature fish because the mode for $P$. aethiopicus was $47-56 \mathrm{~cm}$ TL during September 2002 survey, and $36-37 \mathrm{~cm}$ TL in January 2003, while in Lake Victoria, the length at first maturity for $P$. aethiopicus had been found to be $66-76 \mathrm{~cm}$ TL for males and 76 - $86 \mathrm{~cm}$ TL for females respectively (Mossile and Mainoya 1988). Clarias gariepinus matures at size of $40 \mathrm{~cm}$ TL for both for males and females (Witte and Van Densen 1995). The establishment of conservation strategies eg CMUs would help to conserve the fish resources. There is thus, need for co-management initiatives in this lake. Disappearence of some species during September 2002 and January 2003 was noted and was mainly attributed to overfishing. However, the dissapearence of Labeo victorianus was due to reproductive behaviour of the fish which normally spawn during the rainy seasons at the margins of the rivers 15 to $30 \mathrm{~km}$ upstream (Witte and Van Densen 1995). September and January is a long and short rainy seasons and it is possible that during these periods fishes move upstream for spawning as Lake Kubigena connects with River Mara.

Lake Katwe is a nursery and refugia for a variety of species endemic to Lake Victoria (Katunzi and Kishe 2002, Katunzi 2003). Several other lakes in the Kagera River system (i.e. Lakes Mitoma, Kalenge, Rushwa and Rwakajunju) have similar roles and will be of importance to the replacement of Lake Victoria fish biodiversity if attention is paid to conserve and manage them. The four major tilapiine species in Lake Katwe (i.e Oreochromis niloticus, $O$. variabilis, $O$. esculentus and $O$. leucostictus should be regarded as buffer 
stocks in Lake Victoria natural restocking programmes.

These minor fisheries in the satellite lakes have the potential to provide opportunities for income generation and improvement of nutrition. Local communities depend on these lakes for other livelihood resources. Hence they need to be properly managed for sustainability. The CMUs were envisaged to increase the effectiveness of regulating the fishery and minimizing user conflicts, because most of the satellite lakes are in very remote areas where the government can not adequately monitor and enforce the existing fisheries regulations. Therefore, such initiatives are considered as effective measures to enhance law enforcement (Panayotou 1982), because they become part of the decision making process, sharing responsibilities and possess legal rights in the management for ensuring the sustainability of the fishery (Mc Cay 1993, Cacand 1999).

Fish resources in the satellite lakes are continually declining because of the open access policy to the resources and the continued use of illegal fishing gears and methods. This continual decline of the fisheries have enormous implications on the consumers and those dependent on the fishery for their income. In order to arrest continual decline of fisheries resources found in the satellite lakes, it is recommended to establish surveillence units in places where they are lacking, and offer them some logistical suppoort to enable them undertake the surveillence responsibilities effectively.

\section{REFERENCES}

Cacand P 1999 Review of institutional and legal aspects relating to the management of Lake Tanganyika fisheries. Paper presented at the eight session of the CIFA Sub-committee for Lake Tanganyika. CIFA: DM/LT/99/Inf.7, Rome FAO, 14 pp.

Cowx IG and Welcomme RL 1998 Rehabilitation of Rivers for Fish.
Oxford, Fishing News Books, Blackwell Scientific, 154 pp.

Harris CK 1998 Social regime formation and community participation in fisheries management. In: Pitcher TJ, Hart PJB and Pauly D (eds) Reinventing fisheries management, London, Chapman and Hall, pp. 261-276.

Jentoft S 1989 Fisheries co-management: delegating government responsibility to fishermen's organisations. Marine Policy No. 13: 137-154.

Katunzi EFB 2003 Satellite lakes, rivers and dams as refugia for the endangered fish species of Lake Victoria. In: Ndaro SGM and Kishimba M (eds) Proceedings of the LVEMP Tanzania 2001 Scientific Conference. pp. 4453.

Katunzi EFB and Msuku BS 2001 The biology, ecology and population characteristics of $O$. esculentus in Lake Victoria basin in relation to conservation and restoration of the species. In: Mahongo SB, Chande AI and Katunzi EFB (eds) The biology and ecology of Lake Victoria fisheries. Their development and management. Tanzania version, $\mathrm{pp}$. 46-63.

Katunzi EFB and Kishe MA 2002 Report on Fish Biology, ecology and diversity conservation in satellite lakes of Lake Victoria basin, Tanzania. Report submitted to LVEMP, Dar es Salaam, Tanzania, $48 \mathrm{pp}$.

Lyimo TJ and Sekadende B 2003 A survey of phytoplankton communities in the main lake and satellite lakes of Lake Victoria. In: Ndaro SGM and Kishimba M (eds) Proceedings of the LVEMP Tanzania 2001 Scientific Conference. Pp. 83-92.

Malasha I 2000 The case of Lake Kariba (Zambia). In: Geheb K and Sarch MT (eds) Africa's Inland Fisheries: The management challenge, pp. 89-106. 
Mc Cay B 1993 Management regimes. Paper presented to the property rights and the performance of Natural Resources Systems at Beijer International Institute of Ecological Economics, Stockholm, 12 pp.

Mossile OIIW and Mainoya JR 1988 Reproduction biology of the East African lungfish Protopterus aethiopicus in Mwanza Gulf, Lake
Victoria, Tanzania. African Journal of Ecology 26: 149-162.

Panayotou T 1982 Management concepts for small-scale fisheries. Economic and Socio-aspects. FAO Fisheries Technical Paper 228, Rome, 9pp.

Witte F and Van Densen WLT 1995 Fish stocks and fisheries of Lake Victoria. A handbook for field observations. Samora Publishing Ltd. Samora House, Cardigan UK. 404 pp. 